\title{
THE HÔPITAL SAINT-LAZARE IN PARIS: ITS PAST AND PRESENT HISTORY
}

\author{
BY \\ PAUL BLUM \\ Formerly Chef de Clinique, Paris Faculty of Medicine; Senior Physician to the Hôpital de Saint-Lazare
}

The Saint-Lazare Hospital and its annexes are situated near the Gare de l'Est, more or less on the site of the old prison of Saint-Lazare which used to occupy number 107, Faubourg Saint-Denis. The buildings stretch from Faubourg Saint-Denis as far as La Cour de la Ferme Saint-Lazare. The front entrance is at 9, Cour de la Ferme Saint-Lazare. It is a magnificent modern building, built and planned according to the latest ideas in contemporary architecture. The Saint-Lazare is a fullyequipped medico-social and hospital centre, and it is intended mainly for so-called femmes de moeurs légères suffering from venereal disease. It has not always served the same purpose, and it will be interesting to trace its past history briefly.

\section{Saint-Lazare, from its Origins to the Present Day}

Its origin goes back to the eleventh century. At that far distant epoch Saint-Lazare was a wellknown institution for lepers. This place was built on the ruins of the ancient abbey of Saint-Laurent, destroyed by the Normans in 886 , and dedicated to Saint-Ladre, otherwise Saint-Lazare. He was the brother of Martha and Mary, Christ's friends, and was not the poor Lazárus of St. Luke's Gospel, as was popularly believed at one time. This hosptial for lepers was at that time very famous and enjoyed the protection and financial help of many kings. It lay on the route from Paris to Saint-Denis and was frequently visited by the great people of that day. But the leper colony itself was open only to lepers from Paris and, very exceptionally, to bakers from the entire kingdom, because of their great professional risk of contracting the malady.

This leper asylum seems to have persisted till about 1630. It was then in a dilapidated condition. From 1630 to 1660 the establishment was taken over by Saint Vincent de Paul, who rebuilt the old structures and created new ones. Saint Vincent de Paul, his priests of the Mission, the Lazarite Fathers, and, from 1634, the Sisters of Charity, did magnificent work : there the sick and wounded, abandoned children, and destitutes of all categories found asylum and help, and food was distributed to them. More than 20,000 people were admitted and treated with great devotion. "Saint-Lazare has become a sort of Noah's Ark, where all sorts of animals great and small are admitted and fed," wrote " Monsieur Vincent." And so the Saint-Lazare institution propagated a great work of Christian charity under Saint Vincent de Paul, he himself occupying only the small monastic cell in which he died in 1660.

Such men as Saint Francis de Sales, Bossuet, Flechier, Turenne, Condé, Richelieu, and Mazarin have passed through the quiet alleys of these buildings. The silver bell which used to ting in the ancient tower was a gift from the great Queen Anne of Austria.

About the end of the seventeenth century SaintLazare ceased to be a convent and was used to harbour prisoners, young depraved men, undisciplined priests, insane people, and others.

During the Revolution, from July 15, 1789, Saint-Lazare was pillaged. The priests of the Mission were driven away, everything was stolen or sold, and the place was filled with suspects, men and women locked up and awaiting trial. During the dreadful times of the Terror Saint-Lazare thus became the waiting-room for those destined for the guillotine. Among the victims detained there was the celebrated poet, André Chénier, who composed The Young Captive before dying on the scaffold.

After December, 1794, no more prisoners were detained; France was again free. A decision by the Convention transformed Saint-Lazare into a prison for women (December 15, 1794, or 25 Frimaire, year III). All the women imprisoned in Vincennes, la Force, and Salpétrière, were transported to the new Saint-Lazare prison.

Little by little Saint-Lazare became the abode of all sorts of women convicts : criminals, thieves, spies, prostitutes, etc. Among them there were so many infected with venereal disease that a special infirmary became indispensable. This was built 
between 1824 and 1836, and was used to segregate the women infected with venereal disease from the rest.

In 1850 Saint-Lazare was fully organized: the law section (section judiciaire) was separated from the section for debauched women and minors. At that time the so-called Sisters of the Prisons of the Order of Marie-Joseph kept order in both sections of the Saint-Lazare institution and tried to introduce some discipline into the-lives of these unruly adventuresses.

There was no change until 1932, when 'those detained in the first section were transferred to la Roquette. The prostitutes with venereal infection remained in Saint-Lazare.

From 1935 onwards the last remains of the old prison were done away with. New buildings were constructed, and in 1937 the rebuilt Saint-Lazare was inaugurated.

\section{The Present Saint-Lazare}

The new hospital of Saint-Lazare stands behind the large gardens in the Faubourg Saint-Denis. Immediately in front of it is the residence of the Sisters of the Order of Marie-Joseph. The hospital contains four hundred beds, and its entrance is at the end of the rue de la Ferme Saint-Lazare.

The present Saint-Lazare is a modern hospital with up-to-date equipment, a dispensary, and pathological laboratories. The ward units and the special departments are staffed by doctors selected by competition from the staffs of Paris hospitals, and specialists in venereology trained in the hospitals of Saint-Louis and Saint-Lazare. They are helped by religious Sisters, lay nurses, and almoners.

The Hospital is essentially a medico-social centre comprising many different departments.

The Main Hospital.-The hospital of SaintLazare itself is staffed by the Sisters of Marie-Joseph. The patients stay there until they are completely free from venereal infection. While in patients, they are taught needlework and sewing. They cannot leave the hospital until certified non-infectious. In 1947 there were more than 2,000 female in patients, of whom 260 had an active syphilitic infection and nearly 600 had acute gonorrhœa.

The Receiving Ward.-Women are seen before admission in the Saint-Lazare receiving ward. A thorough investigation into the medical history and social circumstances of these women is made by the chief physician and his assistants, helped by men from the Office of Social Welfare, by social workers, and by an almoner. The so-called assistantes sociales (assistant almoners) question and investigate each case from the social point of view, while the doctors make a diagnosis and decide whether the patient should be admitted. More than 12,000 women are examined annually in this department.

Le Dispensaire de Salubrité.-The Health Dispensary, once situated at 3, Quai de l'Horloge, near the Conciergerie, where women were once forcibly brought for examination, is today a centre for medical examinations. Its services are given freely to patients coming of their own free will. Bacteriological and serological tests are performed on more than 3,000 women and girls per year, and those needing in-patient treatment are admitted.

The Toussaint-Barthélemy Dispensary.-Treatment to patients of both sexes is available at the ToussaintBarthélemy Dispensary. Women who started treatment at the Saint-Lazare Hospital and who are fit to continue as out patients are also seen there. This dispensary deals with syphilis, gonorrhœea, urology, and gynæcology cases. More than 80,000 consultations are given each year.

In addition, two laboratories for pathological investigation and research deal with 20,000 serological tests and 12,000 bacteriological examinations a year.

General Functions.- Thus, Saint-Lazare was transformed from a penitentiary and prison into a great medico-social centre for the treatment of venereal diseases among women, and specially among the so-called femmes de moeurs légères. The social work done here is not less important than the medical. Epidemiological investigations are carried out, and possible sources of contamination are traced and contacts examined. Special protection and care is given to young girls. Social service workers deal with those who attend irregularly, and they also take care of pregnant women, as well as the sick (suffering from heart disease, tuberculosis, and neurological complaints). Their assistance is invaluable in the rehabilitation of prostitutes, for whom work is found and who are followed up in their new careers. There is close co-operation with other organizations for the protection of women.

This, then is the Saint-Lazare of today. Many do not know of its existence, others are ignorant of its accomplishments and are still full of prejudices. This institution, which is of such vital medical and social importance, deserves to be more widely known. 